CAHIER DE RECHERCHE \#1718E

Département de science économique

Faculté des sciences sociales

Université d'Ottawa
WORKING PAPER \#1718E

Department of Economics

Faculty of Social Sciences

University of Ottawa

\title{
Carbon Tax Saliency: The Case of B.C. Diesel Demand*
}

\author{
Jean-Thomas Bernard ${ }^{\dagger}$ and Maral Kichian ${ }^{\ddagger}$
}

December 2017

\footnotetext{
${ }^{*}$ We would like to thank Rebecca Jacobs and specially Misbahul Islam for research assistance. We also gratefully acknowledge the financial support of the Social Sciences and Humanities Research Council of Canada.

${ }^{\dagger}$ Department of Economics, University of Ottawa, 120 University Private, Ottawa, Ontario, Canada, K1N 6N5; e-mail: jbernar3@uOttawa.ca.

₹ Graduate School of Public and International Affairs, University of Ottawa, 120 University Private, Ottawa, Ontario, Canada, K1N 6N5; e-mail: mkichian@uottawa.ca.
} 


\begin{abstract}
In 2008, the government of the province of British Columbia broke new ground in North America by introducing a revenue-neutral carbon tax on fossil fuels. The initial rate was set at \$10/ton of $\mathrm{CO}_{2}$ which was then increased annually by \$5 increments to reach \$30/ton in 2012. We focus on monthly diesel use which is mostly related to commercial activities. Our objective is to measure user reaction to the new tax. Exploiting the sample time series properties, we study the long run reaction via a cointegration equation, linking diesel use, its total price, and income, and the short run reaction using an error correction model (ECM). Carbon tax saliency is interpreted as a short run phenomenon that shows up in the dynamic adjustment of the ECM. We find that the long run total price elasticity estimate of diesel demand is -0.52 and that the short run tax saliency effect is statistically significant. However, the total reaction is small relative to Canada's commitment to decrease GHG emissions by 30\% in 2030 relative to 2005 levels.
\end{abstract}

Key words: diesel demand, carbon tax, tax saliency.

JEL Classification: Q41, Q58, H23 


\section{Introduction}

In policy discussions regarding the most appropriate instrument to choose for reducing greenhouse gas emissions due to fossil fuel use, a carbon tax has received widespread support from economists. ${ }^{2}$ However, in order to empirically quantify the effects of such a new tax on fossil fuel demand, appropriate price elasticity estimates need to be obtained. While a large set of gasoline and diesel price elasticity estimates is readily available from existing studies, the bulk of these studies use the total price paid by consumers as an explanatory variable in the specified demand model; Dahl (2012) presents a survey. Such an approach is in agreement with the canonical neoclassical economic theory that treats all the components of prices in the same way: a dollar is a dollar. However, there is a growing literature that questions this tenet; in particular, do people react in the same way to tax changes as they do to changes in other components of prices that are market determined? ${ }^{3}$ Recent studies such as Davis and Kilian (2011) and Li et al. (2014) provide empirical support for the proposition that U.S. gasoline taxes have a larger impact on demand than net-of-tax prices (that are mostly made up of crude oil prices).

In this paper, we explore the above-mentioned issues in the context of a unique policy initiative, at least in North America, where the government of the province of British Columbia (B.C.) introduced a revenue-neutral carbon tax on a broad range of $\mathrm{CO}_{2}$ emissions originating from fossil fuel use. The tax rate was set at $\$ 10 /$ ton of $\mathrm{CO}_{2}$ in July 2008 and increased by $\$ 5$ on July of every year to reach $\$ 30$ in $2012 .{ }^{4}$ We focus on monthly diesel domestic sales from July 2008 to December 2013. According to the B.C. Ministry of Environment (2010), the province emitted 68.71 million tons of $\mathrm{CO}_{2}$ in 2008 , and 10.04 million tons were the result of diesel use; thus the latter represented $14.6 \%$ of

\footnotetext{
${ }^{2}$ A recent example is Bushnell (2014).

${ }^{3}$ Chetty et al. (2009) provide a cogent illustration and they emphasize the role played by tax saliency.

${ }^{4}$ All values are expressed in Canadian dollar, except where it is indicated otherwise.
} 
total emissions, and $18.2 \%$ of energy emissions. The province of B.C. consumed 3732.6 mega litres $(\mathrm{mL})$ of diesel in that year. Although total transportation was the largest single user $(2044.1 \mathrm{~mL})^{5}$, significant quantities of diesel were also consumed by other sectors of the B.C. economy: commercial and other institutions $(827.1 \mathrm{~mL})$, industry $(646.2 \mathrm{~mL})^{6}$ and agriculture $(140.1 \mathrm{~mL})$. Hence diesel use is present in major sectors of the B.C. economy and it is related mostly to commercial activities.

Our research questions are as follows: first, is there a cointegration function linking diesel use to total price and income over the sample period, and if such a function exists, what is the associated long run price elasticity estimate? Second, do we find additional short run effects related to diesel price that is net of carbon tax (denoted hereafter as price net-of-carbon-tax) and to carbon tax? If such short run effects are present, do they differ? That is, is there evidence of short run carbon tax saliency? More precisely, given the long run relationship between quantity and total price of diesel, are there separate short run effects of diesel price net-of-carbon-tax and of carbon tax that can be uncovered in the dynamic adjustment part of the error correction model (ECM)? Third, given that the carbon tax increased by equal increments over a four-year period, can we observe changes in the saliency of the tax over time? To the best of our knowledge, our paper is the first to use the time series methodology (i.e. cointegration and ECM) to analyze the saliency of carbon tax applied to refined oil products, and to examine for possible time-varying effects of the latter on diesel demand.

The study that comes closest to ours is that of Rivers and Schaufele (2015) where the authors studied the saliency of B.C. carbon tax on gasoline demand. ${ }^{7}$ However, despite focusing on the same topic, there are important differences between the two studies. First, gasoline and diesel demands belong to different sectors of the economy that have their own specific features. Gasoline demand is

\footnotetext{
${ }^{5}$ Road transportation accounted for $1502 \mathrm{~mL}$ of total transportation and the bulk (97.8\%) is related to operations of heavy duty vehicles. Marine and railway transportation accounted for the rest of total transportation.

${ }^{6}$ Mining, oil and gas $(271.2 \mathrm{~mL})$, forestry $(137.3 \mathrm{~mL})$, construction $(155.4 \mathrm{~mL})$ and other $(79.3 \mathrm{~mL})$..

${ }^{7}$ See also Antweiler and Gulati (2016)
} 
mostly related to household activities such as work, school, shopping and leisure. Moreover, a significant number of B.C. car and small truck owners live close to the U.S. border and are able to shop in nearby U.S. towns; they might use this occasion to fill their vehicle tank. This would decrease B.C. gasoline purchase without affecting B.C. gasoline consumption. Diesel users, on the other hand, are constrained in this respect, since Canadian provinces joined the International Fuel Tax Agreement (IFTA) in the mid-nineties, and carriers pay diesel tax on the basis of distance traveled rather than purchase location. However, many commercial diesel users own storage tanks, which allow them to shift their purchases over time to partially hedge against announced tax increases. These potential lead and lag adjustments have to be taken into consideration when evaluating the net effect of the tax change. Household gasoline users may also adopt this strategy, but they are limited by the tank capacities of their cars and small trucks. ${ }^{8}$

Second, the applied methodologies are different. Rivers and Schaufele (2015) use a panel approach while we prefer to apply a time series strategy. A panel setup is meant to exploit interprovincial differences that might exist in order to better characterize the average impacts of price and carbon tax on gasoline consumption, but this advantage is not so obvious in the current case. Only two of the ten Canadian provinces (B.C. and Quebec $^{9}$ ) had applied a carbon tax over this sample period, and the degree of inter-provincial gasoline price correlation is very high. Furthermore, climate and economic conditions vary across the provinces and across time and this may create parameter heterogeneity not necessarily captured by fixed and time effects within the panel.

Third, our analysis is able to depict a more complete picture of how the economy reacts over time to price and tax changes. While the study of Rivers and Schaufele (2015) can only reveal short-

\footnotetext{
${ }^{8}$ See Coglianese et al. (2015)

${ }^{9}$ Quebec was collecting a small carbon tax of $\$ 3.00 /$ ton, which amounts to less than $1 \mathrm{c} /$ litre of gasoline.
} 
run impacts, our approach is able to inform on both the short-run and the long-run responses to price and tax changes over the sample period. ${ }^{10}$

Our main conclusions are as follows. First, statistical tests show the presence of unit roots in the levels of the three key variables i.e., diesel consumption per capita, diesel price, and income per capita, and the stationarity of first differences of the above series is not rejected. Second, Johansen test results conclude that there is one cointegrating relationship linking diesel consumption per capita, diesel price, and income per capita over the sample period. The application of the dynamic ordinary least squares (DOLS) method introduced by Stock and Watson (1993) to estimate the linear cointegration function yields a long run price elasticity of -0.52 estimated at the sample average. Third, the estimation of an error correction model that allows for dynamic adjustments points to additional short run effects that are associated with the introduction of the B.C. carbon tax but not with changes of price net-of-carbon-tax. Hence our results support the view that the B.C. carbon tax applied to diesel use displays saliency. Fourth, according to our parameter estimates, a 1 cent increase in carbon tax induces a one-time decrease in monthly per capita diesel sales of 4.17 litres (or $6.7 \%$ of average monthly sales over the sample period). Fifth, we find evidence of time-variation of this impact over the $2009-2012$ period.

The paper proceeds as follows: section 2 introduces the neutral carbon tax that has been implemented in B.C.; section 3 includes the literature review; section 4 describes the data and section 5 presents the econometric models and the estimation results. We conclude with some comments on related policy issues.

\footnotetext{
${ }^{10}$ Murray and Rivers (2015) present a policy assessment of B.C. carbon tax.
} 


\section{The B.C. Carbon Tax}

University economists played an active role in the inception of an explicit tax on carbon emissions in the province of British Columbia. During a community meeting in October 2007 where global warming issues and related policy interventions were discussed, the B.C. premier asked a participant, David Green, who is a UBC professor of economics, to present the argument in favour of a revenue-neutral carbon tax. Following the invitation, an open letter that was signed by 70 economists from the four main university campuses in B.C., was addressed to the finance minister on November $1^{\text {st }} 2007^{11}$. The government took action in the next few months and B.C. became the first North American jurisdiction to introduce a significant and broad-based tax on carbon emissions from fossil fuel consumption. ${ }^{12}$ The unique experience of B.C. carbon tax is now part of a policy forum in North America ${ }^{13}$ and it has received the support of the Editorial Board (2016) of The New York Times to address GHG emission.

The B.C. government made public its plan to impose a carbon tax in its February 2008 budget. ${ }^{14}$ The main features of this new tax on fossil fuel consumption, including gasoline, diesel, natural gas, coal, propane, and home heating fuels, are as follows. The new carbon tax was to be phased in through five annual increments: the initial rate was set at $\$ 10 /$ ton starting on July $1^{\text {st }} 2008$ and the rate was to increase by $\$ 5 /$ ton every July $1^{\text {st }}$ up to 2012 to reach $\$ 30 /$ ton. This is equivalent to $2.69 \mathrm{c} /$ litre of diesel, rising to $7.68 \mathrm{c}$ in $2012^{15}$. A very interesting feature of the new carbon tax was

\footnotetext{
11 Green(2007).

12 Since 2007, the province of Quebec requires that fossil fuel distributors pay a tax of $\$ 3 /$ tonne of $\mathrm{CO}_{2}$, i.e. 0.7 cents/litre of gasoline. This tax yields approximately $\$ 200$ million per year that are used to fund environmental initiatives. Also since 2007 Alberta regulates the large industrial companies that emit more than 100,000 tons of $\mathrm{CO}_{2}$ per year to reduce emissions intensity by $12.0 \%$ or pay $\$ 15 /$ ton of emissions above the threshold. On November 22,2015 the newly elected NDP government of Alberta announced that it will gradually implement a broad based carbon tax quite similar to British Columbia that will reach 30\$/ton on January 1st, 2018.

13 See Resources for the Future (2016).

${ }^{14}$ B.C. Ministry of Finance (2008).

15 This represents a price increase of $5.72 \%$ per litre of diesel with respect to July 2012 average price.
} 
its revenue neutrality. All the revenues were to be returned to individuals and businesses through tax reductions. The lowest two personal income tax rates were to be decreased to provide a tax cut of $2.0 \%$ in 2008 , and $5.0 \%$ in 2009 , respectively, on the first $\$ 70,000$ earnings for every individual. Effective on July $1^{\text {st }}, 2008$, the general corporate income tax rate was also reduced, from $12.0 \%$ to $11.0 \%$ and then to $10.0 \%$ in 2011 . Similarly the small business income tax rate was cut from $4.5 \%$ to $2.5 \%$ over the same period. The income threshold between small businesses and general corporations was increased from $\$ 400,000$ to $\$ 500,000$. Finally a new annual tax credit of $\$ 100$ per adult and $\$ 30$ per child was to be provided to low income residents. It was also decided that the minister of finance would publish an annual report describing how the carbon tax revenues were used to ensure neutrality.

The carbon tax has been rather well received by British Columbians. According to a poll conducted by the Pembina Institute, "69.0\% of B.C. residents are worried about global warming and 70.0\% support the province being a leader in taking action to solve the problem. $36.0 \%$ believe that reducing greenhouse gas pollution helps grow or $44.0 \%$ has little impact on B.C.'s economy." ${ }^{16}$ Figure 1 shows the relative (to the peak of July 2008) evolution of interest in the B.C. carbon tax as registered by web searches from 2007 to the present. The interest indicator jumped with the announcement of the February 2008 budget and reached an all-time peak when the tax became effective on July $1^{\text {st }} 2008$. Very small bumps occurred on July $1^{\text {st }}$ of every ensuing year until 2012 . Such a display of interest over time may lead to a tax saliency effect. The B.C. carbon tax has unique features in this respect: first, the explicit policy objective is to reduce greenhouse gas emissions; second, it is designed to be revenue neutral so that there is no change in government budget; third, it

\footnotetext{
${ }^{16}$ Home (2011).
} 
was announced well before implementation, giving time to users to plan their adjustment, and finally, implementation took place over five years.

\section{Literature Review}

Because of widespread policy interests and availability of reasonably good data, a large set of papers have been published on gasoline and, to a lesser extent, on diesel demand, with particular interest for price and income elasticity estimates. Dahl (2012) presents an extensive survey of estimates obtained from a static model specification for 124 countries $^{17}$. The median price elasticity estimate of diesel demand is -0.16 , a smaller value than gasoline -0.34 . The lower demand elasticity of diesel relative to gasoline is expected since diesel users may have the opportunity to pass price increases onto their customers. This is likely to occur since providers of similar services often make use of similar equipment, hence face similar cost changes.

The study that is closest to ours in terms of product, region, objective and methodology is Barla et al. (2014). They estimate a model of demand of road diesel in Canada using annual data spanning the period 1986 -2008. The explanatory variables are diesel price, income per capita, the share of primary sector in total GDP, and a time trend. They apply the Engel-Granger methodology to estimate the cointegration model and use an error correction model. ${ }^{18}$ From the cointegration model, they obtain a long run price elasticity estimate of -0.42 while the autonomous annual growth is $1.5 \%$. From the corresponding ECM, the short run price elasticity estimate is reported to be -0.15 .

Our work differs from Barla et al. (2014) in several aspects: first, we use monthly data on total diesel domestic sales, and in one Canadian province only, and our sample covers the period 20082013. Second, we apply Johansen tests to analyze the number of cointegration relationships and the

\footnotetext{
17 She asserts that static specification could be interpreted as a long run cointegration relationship.

${ }^{18}$ Barla et al. (2014) estimate also a partial adjustment model.
} 
Stock and Watson (1993) dynamic OLS (DOLS) method to estimate the long run cointegration linear function. Third, we introduce lead and lag effects in the ECM specification. Fourth, we focus on saliency of the carbon tax.

\section{Data}

The sample that we use to analyze the effects of the B.C. carbon tax on diesel demand runs from July 2008 to December 2013, and we focus in particular on the impacts of the tax changes incurred from 2009 to 2012. There is because many significant economic events simultaneously affected the B.C. economy and diesel demand in 2008. In addition, the evolution of oil price was subject to large swings over this period.

More specifically, the following factors were operating at the same time: (i) the U.S. economy moved into the Great Recession and the Canadian economy followed with a lag ${ }^{19}$. (ii) The so-called shale gas revolution was in full swing in the U.S. and had a dramatic impact on natural gas price that went from \$11.78/thousand cubic feet in July 2008 to $\$ 6.76$ in November 2008 and to \$2.86 in September 2009. ${ }^{20}$ The shale gas revolution had two opposite effects on the B.C natural gas sector: on the one hand, it lowered the value of conventional gas deposits and on the other hand, it opened a whole new resource made of large shale gas deposits in the North East region. (iii) Oil price evolved very erratically around this time. In the nineties, the average annual nominal price of crude oil remained below $20 \$ /$ barrel; in 2000 , it moved upward to $26.27 \$$ and kept increasing to reach $93.33 \$$ /barrel in $2008^{21}$. The Great Recession brought it down to $63.23 \$$ / in 2009 ; it resumed its upward march and stayed above $100.00 \$ /$ barrel from 2010 to the first few months of 2014 . The year

\footnotetext{
${ }^{19}$ According to NBER dating, the U.S. economy moved from a peak in the last quarter of 2007 to a trough in the second quarter of 2009. Canada's economy reached a peak in October 2008 and a trough in May 2009.

${ }^{20}$ Average import price from Canada in U.S. dollar. See Energy Information Administration.

${ }^{21}$ Average landed cost of U.S. crude oil imports in U.S. dollar. See Energy Information Administration.
} 
2008 witnessed a particularly large swing; oil price reached an all-time nominal peak at \$147.00 in July, fell to $\$ 35.00$ in December and reverted to an increasing trend afterward. These large swings imply possibly asymmetric effects of oil price changes ${ }^{22}$.

All the above factors were operating simultaneously in July 2008 when the carbon tax that had been announced five months earlier was first introduced, and it is difficult to sort out all of their separate effects. We focus on the tax impacts from 2009 onwards to avoid confounding the influence of possibly other factors with the 2008 carbon tax effect. Any evidence of saliency found under these conditions therefore likely underestimates its total extent.

Our sample includes B.C. monthly data on domestic sales of diesel, diesel price net-of-carbontax, carbon tax, gross domestic product (GDP), population and consumer price index from July 2008 to December 2013; the Appendix shows the source of each variable. The diesel price net-of-carbon-tax is inclusive of the $5 \%$ good and service tax (GST) and the excise tax. ${ }^{23}$

Figure 2 presents diesel sales per capita; after the huge drop in the last quarter of 2008, diesel sales displays a seasonal pattern around an upward trend. Figure 3 shows the real diesel price net-ofcarbon-tax and the real carbon tax over the sample period. The first variable follows closely the path of oil price described above; it decreased sharply in the last two quarters of 2008 , it increases steadily in 2009 and 2010, and it stayed close to a plateau from 2011 to 2013. The real carbon tax increased five times in July 2008 to July 2012 and it was slowly pushed downward by inflation. The evolution of real GDP per capita appears in Figure 4; there is a large drop in the last quarter of 2008 and in the first

\footnotetext{
22 There is a large literature on the asymmetric response of oil demand to positive and negative price changes. See Degiannakis et al. (2017).

${ }^{23}$ The federal and provincial government each collect their own excise tax. The sum of the two taxes was $19.5 \mathrm{c} /$ litre in January 2008; 3.0c were added on January 2010 and 2.0c on April 2012.
} 
quarter of 2009. Then it moved upward with some minor bumps. For further analysis, diesel price netof-carbon-tax, diesel sales per capita and GDP per capita are deseasonalised. ${ }^{24}$

\section{Methodology, model specifications and estimation results}

The methodology and the model specification are selected to shed some light on the following three aspects: a possible long run demand relationship linking diesel use, total diesel price and income, short run dynamic adjustment of diesel demand that allows for carbon tax saliency, and potentially time varying impacts of carbon tax changes. Our sample consists of monthly data, and the time series properties of the variables have to be taken explicitly into account in order to arrive at robust results. In this regard, we build on the strategy of Cuddington and Dagher (2015): first, we test for the presence of unit roots in the variables; second, we test whether the non-stationary variables are cointegrated using Johansen and Engle-Granger tests; third, we estimate the parameters of the long run equation by applying Dynamic OLS (DOLS) introduced by Stock and Watson (1993); and finally, for the short run analysis, we apply an error correction model (ECM). At this stage we also perform tests for carbon tax saliency and time varying effects in the context of our ECM framework.

The initial concern is whether there is cointegration amongst the three variables of interest: diesel sales per capita $\left(D_{t}\right)$, total price of diesel $\left(P_{t}\right)$, which is defined as the sum of deseasonalised real diesel price net-of-carbon-tax $\left(P X C T_{t}\right)$ and of real carbon tax $\left(C T_{t}\right)$, and GDP per capita $\left(I_{t}\right)$; hence we first test for the presence of unit roots. Table 1 shows the statistics associated with the application of the Augmented Dickey Fuller (ADF) and the KPSS tests to levels and first differences of the observed variables. ${ }^{25}$ It can be seen that the ADF tests point to the presence of a unit root in the level of per

\footnotetext{
${ }^{24}$ Coefficients of monthly dummies are calculated by OLS. All the estimations in the paper are performed using EViews 10.

25 Tests are applied to levels of the variables measured in natural units; logarithmic transformation of the variables leads to the same conclusion.
} 
capita diesel sales and of GDP but not for diesel price, while the KPSS tests indicates non-stationarity of price and of GDP per capita, but not for diesel sales. Thus we conclude that the series in levels have unit roots. In addition, the two sets of tests show that there are no unit roots in the first difference of all the variables.

The next step is to analyze the number of cointegration relationships. ${ }^{26}$ We consider carbon tax saliency to be a short run phenomenon and that, in the long run, all components of total price produce identical effects. Table 2 displays the results of the application of Johansen trace and maximum eigenvalue cointegration tests. Both indicate at the $5 \%$ significance level that there is only one cointegration relationship between our three variables. As in Cuddington and Dagher (2015), we also apply exogeneity tests and we find that diesel price is weakly exogenous. This result is expected since the main factor behind the diesel price is the oil price and the latter is determined at the world level. Hence we consider per capita domestic diesel sales as our dependent variable in the long run relationship.

We use the Dynamic OLS (DOLS) method proposed by Stock and Watson (1993) to estimate the following linear cointegration function:

$$
D_{t}=C+\beta_{P} P_{t}+\beta_{I} I_{t}+\sum_{i=-n}^{n} \delta_{P i} \Delta P_{t-i}+\sum_{i=-k}^{k} \delta_{I i} \Delta I_{t-i}+v_{t}
$$

where $\Delta$ is the first-difference operator, $n$ and $k$ are the number of leads and lags considered, and $v_{t}$ is the error term. Stock and Watson (1993) propose to introduce leads and lags of first differences to account for possible autocorrelation in the residuals. Standard t-statistics can then be used to perform usual tests. Table 3 presents the estimation results of the application of DOLS ${ }^{27}$. It can be seen that GDP per capita is highly significant while total diesel price is statistically significant at the

\footnotetext{
${ }^{26}$ In theory, there exist at most two cointegrating relationships between three variables.

27 Although we considered several values for $n$ and $k$, we selected $n=1$ and $k=1$ as they provided the best model fit.
} 
$10 \%$ level. At the sample mean, this yields a long run price elasticity estimate of -0.52 which is higher than the estimate of -0.42 obtained by Barla et al. (2014) and higher than the median value of -0.16 reported in Dahl (2012).

As in Stock and Watson (1993), estimated long run residuals (denoted $\widehat{L R R_{t}}$ ) are obtained by subtracting the fitted long run part of each observation from its corresponding value for the dependent variable. A unit root test is then conducted on the resulting series. The test outcome is reported at the bottom of the Table 3 and it shows that the null hypothesis of a unit root is strongly rejected. Hence the Engle-Granger (E-G) test result also supports the proposition that there is one cointegration relationship linking $D_{t}, P_{t}$ and $I_{t}$.

Using these estimated long run residuals, we postulate the following general error correction model (ECM1):

$$
\Delta D_{t}=C_{1}+\gamma_{1} \widehat{L R R_{t-1}}+\sum_{i=0}^{3} \alpha_{1 P i} \Delta P X C T_{t-i}+\sum_{i=-3}^{3} \alpha_{1 C i} \Delta C T_{t-i}+\sum_{i=0}^{6} \alpha_{1 I i} \Delta I_{t-i}+\varepsilon_{1 t}
$$

The equation includes possible lag effects related to changes of diesel price-net-of-carbon-tax up to order 3 and to changes of GDP per capita up to order 6 . It also allows for changes of carbon tax to have both lead and lag effects of order 3 . The lead effects are included to take into account the fact that carbon tax rate changes were announced several months before their application.

The estimation results for ECM1 are reported on the left-hand side of Table 4 . The adjustment coefficient estimate is statistically significant, large in absolute value and negative, providing support for our error-correction modelling strategy. In addition, we find that none of the coefficients associated with changes in diesel price net-of-carbon-tax were significant. Therefore, once we take into consideration the long run price effect, there are no significant additional short run effects associated with changes in price net-of-carbon-tax. On the other hand, we find that changes in the 
carbon tax do play a significant role in the short run, with an impact of -4.05 litres/cent that occurs after 3 months.

To ascertain further the appropriateness of our fitted model, the bottom part of Table 4 reports the adjusted R-square of the regression and also shows the results ( $p$-values) of various diagnostic checks. In particular, we examine whether there is any remaining autocorrelation or heteroskedacticity in the residuals, and whether the latter are normally distributed. We find an adjusted R-square value of 0.50 for our fitted model. We also find that we cannot reject the null of no autocorrelation, whether it is of order 1 or of order 4 , at the $5 \%$ level. Similarly, we cannot reject the absence of ARCH effects. Finally, we cannot reject normality of the residuals. Thus our model is wellspecified and explains a fair proportion of the movements in per capita diesel demand.

Taken together, our results so far support the proposition that the carbon tax displays significant short run saliency, and that its impact is relatively important. Moreover, while price matters for demand in the long run, changes in the price net-of-carbon-tax play no role in the short run.

In ECM1, changes in real carbon tax over the whole sample are considered, and their average impact is captured via the coefficients $\alpha_{1 C i}$. Examining the evolution of this series more carefully, we see that the main changes in real carbon tax are the identical nominal jumps that occur in the months of July each year over the period 2009 to 2012 , and which slowly get eroded by inflation. Since carbon tax saliency, if it exists, should mostly be visible when the jumps occur each July, it is worthwhile examining whether these jumps are really driving the previously-reported carbon tax impact. We thus modify our model slightly to specify the following equation (denoted ECM2) and given by:

$$
\Delta D_{t}=C_{2}+\gamma_{2} \widehat{L R R_{t-1}}+\sum_{i=0}^{3} \alpha_{2 P i} \Delta P X C T_{t-i}+\sum_{i=-3}^{3} \alpha_{2 C i} \Delta C T_{t-i} J_{t-i}+\sum_{i=0}^{6} \alpha_{2 I i} \Delta I_{t-i}+\varepsilon_{2 t},
$$


where $J_{t-i}$ is a dummy variable that takes a value of 1 in the July months of 2009 to 2012 , and 0 otherwise. The rest of the variables in the model are as in ECM1. The estimation results appear in the middle section of Table 4. It can be seen that focusing only on the July rise of the carbon tax rate causes little change in the parameter estimates of the model; in ECM2, only the coefficient of the carbon tax change is slightly larger in absolute value, i.e. -4.175 compared to -4.05 . This result therefore provides additional support for carbon tax saliency.

Having shown that carbon taxes are salient, we now examine its evolution over time. The B.C carbon tax was announced in the February 2008 budget and the nominal increment of 1.28c/liter was added on each July month, from 2009 to 2012. These identical-amount increases in tax provide us with a unique opportunity to examine how diesel users adjust their consumption with regard to these similar changes over time. In other words, is their response time-varying? To capture this possibility, we modify the ECM further (which we denote as ECM3) as follows:

$$
\begin{aligned}
\Delta D_{t}= & C_{3}+\gamma_{3} L \widehat{R R_{t-1}}+\sum_{i=0}^{3} \alpha_{3 P i} \Delta P X C T_{t-i}+\sum_{i=0}^{6} \alpha_{3 I i} \Delta I_{t-i}+\sum_{i=-3}^{3} \alpha_{3 c i}^{09} \Delta C T_{t-i} J_{t-i}^{09}+ \\
& \sum_{i=-3}^{3} \alpha_{3 c i}^{10} \Delta C T_{t-i} J_{t-i}^{10}+\sum_{i=-3}^{3} \alpha_{3 c i}^{11} \Delta C T_{t-i} J_{t-i}^{11}+\sum_{i=-3}^{3} \alpha_{3 c i}^{12} \Delta C T_{t-i} J_{t-i}^{12}+\varepsilon_{3 t}
\end{aligned}
$$

where $J_{t-i}^{z z}$ is the July dummy of year $z z$, where $z z=09,10,11$, and 12 .

In the above specification, each year's July carbon tax increment is allowed to induce a different consumer response (including possibly via its leads or lags). The estimation results are displayed on the right hand side of the Table 4 . We first note that the more flexible specification of consumer response to tax changes causes an increase in the adjusted R-square from 0.5 to 0.6 , while the diagnostics checks show that the fitted model is also well-specified. In addition, all the parameter coefficient estimates of non-tax variables are practically unchanged from the previous ECM specifications. Moreover, we find that some but not all the yearly tax dummies are significant. We 
interpret these results, along with the jump in the adjusted R-square, as support for time-variation in the effects of carbon taxes.

Looking at the yearly dummies more closely, we find significant carbon tax effects only for the years 2011 and 2012. Interestingly, the timing of the impacts also vary from one year to the other: in 2011 the third lag of the tax change has an impact, and the latter is strongly negative at the $5 \%$ level, while in 2012 the 2-month lead has an impact, and this effect is strongly positive at the $10 \%$ level.

It should be noted that our ECM3 specification involves more parameters, and that given our relatively short data sample estimated results should be interpreted with some caution. In particular, our regressions would only be able to detect tax impacts when the latter are quite important in the data, potentially missing smaller tax impacts. However, the observation that certain impacts are picked up by our regression while others are not is in itself evidence in favour of time-variation in the tax effects.

Overall, the results from the three ECM specifications show fairly strong evidence in favour of carbon tax saliency. Furthermore, the third specification indicates that there is variation in this effect over time, and that user behaviour has evolved in this regard.

To provide an assessment of the impact of the B.C. total carbon tax of $7.67 \mathrm{c} / \mathrm{I}$ on diesel sales and on pollution reduction, we take into account both the long run estimated effect associated with the cointegrating relationship (equation 1), and the short run effect. For the latter, we make use of the estimate obtained from ECM2 (equation 3), that is, a decrease of 4.175 liters for one cent of carbon tax increase. We thus estimate that the B.C. carbon tax has induced a permanent reduction in per capita diesel use of -0.266 liters/cent, or -2.04 litres in total. This amounts to a permanent annual decrease of 330,000 tons of $\mathrm{CO}_{2}$ which represents $3.27 \%$ of $\mathrm{CO}_{2}$ emission from diesel in 2008. In 
addition, the total decrease in $\mathrm{CO}_{2}$ emissions associated with carbon tax saliency is a one-time reduction of 385,000 tons; this is slightly larger than the annual permanent decrease. 


\section{Conclusion}

In 2008, the government of the province of British Columbia launched a unique policy experiment by introducing a broad-based revenue-neutral tax on $\mathrm{CO}_{2}$ emissions from fossil fuel products. In this paper we use a new approach to assess the role played by tax saliency and we focus on domestic diesel sales that are mostly related to commercial activities of the various sectors of the B.C. economy. We assume that, in the long run, all the components of price (taxes, prices net-of-tax) have similar effects on demand, and this leads us to posit a cointegration relation between diesel use, total diesel price and income. The resulting estimate of the long run price elasticity is -0.52 . Saliency is considered to be a short run phenomenon, possibly relevant in the dynamic adjustment part of the error correction model. Our estimation results of error-correction models showed that there are significant saliency effects from carbon taxes, but not from diesel price net-of-carbon-tax. Moreover, we found evidence for variation in the tax impacts over time.

The main objective of a revenue-neutral carbon tax is to reduce $\mathrm{CO}_{2}$ emissions that cause global warming. An obvious question that arises in this respect is the effectiveness of the policy instrument in light of the objective. We estimate that the B.C. carbon tax of $\$ 30 /$ ton $\mathrm{CO}_{2}$ brought about a permanent $3.29 \%$ reduction in diesel use. This is however quite small if we consider Canada's commitment to reduce greenhouse gas emission by $30 \%$ in 2030 relative to 2005 emissions, as stated in the 2015 Paris agreement. When we also add the one-time tax saliency effect, which we distribute equally over the 25-year commitment period, the total decrease in emissions would amount to $3.43 \%$ by 2030. Finally, under the assumption that the parameter estimates remain constant and that our estimates for diesel are representative of other fossil fuels, the carbon tax rate would need to jump from $\$ 30 /$ ton to $\$ 262 /$ ton (i.e., a $\$ 20$ annual rise over the next 12 years), in order to meet the Paris commitment. Are B.C. voters ready for such a rise? 


\section{References}

1. Antweiler, W. and S. Gulati (2016) "Frugal Cars or Frugal Drivers? How Carbon and Fuel Taxes Influence the Choice and Use of Cars", Working Paper, University of British Columbia, 35 pages.

2. Barla, P., M. Gilbert-Gonthier and J.R. Tagne Kuelah (2014) "The demand for road diesel in Canada", Energy Economics, 43: 316-322.

3. B.C. Ministry of Environment (2010), British Columbia Greenhouse Gas Industry Report 2008.

4. B.C. Ministry of Environment (2014), Greenhouse Gas Industry Report 2012, http://www.env.gov.bc.ca/cas/mitigation/ghg inventory/pdf/pir-2012-full-report.pdf, accessed May 20, 2016.

5. B.C. Ministry of Finance (2008), Backgrounder, B.C.'s Revenue-Neutral Carbon Tax, http://www.bcbudget.gov.bc.ca/2008/backgrounders/2008_Backgrounder_Carbon_Tax.pdf, accessed April 8, 2014.

6. Bushnell J. (2014) “Cap-and-Trade's Moment of Truth" Energy Institute at Haas, University of California Berkeley, http://energyathaas.wordpress.com/2014/07/14/cap-and-trades-momentof-truth/.

7. Chetty, R., A. Looney and K. Kroft (2009) "Salience and Taxation: Theory and Evidence" American Economic Review, 99(4): 1145-1177.

8. Coglianese, J., L. W. Davis, L. Kilian, and J. H. Stock (2015) “Anticipation, Tax Avoidance, and the Price Elasticity of Gasoline Demand" Energy Institute at Hass, UC at Berkeley, Working Paper 258, 31 pages.

9. Cuddington J.T. and L. Dagher (2015) "Estimating Short and Long-Run Demand Elasticities: A Primer with Energy-Sector Applications" The Energy Journal, 36(1): 185-209.

10. Dahl, C. A. (2012) “Measuring Global Gasoline and Diesel Price and Income Elasticities" Energy Policy, 41: 2-13.

11. Davis L. W. and L. Kilian (2011) "Estimating the Effect of a Gasoline Tax on Carbon Emissions" Journal of Applied Econometrics, 26: 1187-1214.

12. Degiannakis S., G. Filis, and V. Arora (2017) "Oil Prices and Stock Markets: a Review of the Theory and Empirical Evidences", Working Paper, Energy Information Administration, 66 pages.

13. Green, D. (2007), "Why 70 Economists Urge B.C. Carbon Tax", http://thetyee.ca/Views/2007/11/01/CarbonTax/, accessed April 8, 2014. 
14. Home M. (2011) "Measuring the Appetite for Climate Action in B.C., British Columbians' Perspectives on Climate Change and Carbon Tax" Pembina Institute, June 30.

15. Li, S., J. Linn and E. Muehlegger (2014) "Gasoline Taxes and Consumer Behaviour" American Economic Journal: Economic Policy, 6(4): 302-342.

16. Murray B. C. and N. Rivers (2015) “British Columbia's Revenue-Neutral Carbon Tax: A Review of the Latest "Grand Experiment" in Environmental Policy", Energy Policy, 86: 674-683.

17. Resources for the Future (2016) "Tax or Trade: Revising the Trade-Offs in Climate Policy Options" Seminar presented at RFF on March 2, 2016.

18. Rivers, N. and B. Schaufele (2015) "Salience of Carbon Taxes in the Gasoline Market" Journal of Environmental Economics and Management, 74: 23-36.

19. Stock, J.H. and M.W. Watson (1993) "A Simple Estimation of Cointegrating Vectors in Higher Order Integrated Systems" Econometrica, 61(4):783-820.

20. The Editorial Board (2016) "Proof that a Price on Carbon Works" The New York Times, January 19, 2016. 


\section{Table 1}

Unit Root Tests on Levels and on First Differences

\begin{tabular}{|l|ccc|c|}
\cline { 2 - 5 } & \multicolumn{3}{|c|}{ Augmented Dicky Fuller ${ }^{\mathrm{a}}$} & KPSS $^{\mathrm{b}}$ \\
\cline { 2 - 5 } & ADF t-stat & P-value & $\begin{array}{c}\text { AIC lag } \\
\text { choice }\end{array}$ & LM-stat \\
\hline Diesel sales per capita & -2.388 & 0.149 & 2 & 0.250 \\
Total diesel price & -4.600 & 0.002 & 0 & 0.630 \\
GDP per capita & -0.514 & 0.881 & 7 & 0.755 \\
\hline$\triangle$ (Diesel sales per capita) & -7.574 & 0.000 & 1 & 0.158 \\
$\triangle$ (Total diesel price) & -5.734 & 0.000 & 0 & 0.322 \\
$\triangle$ (GDP per capita) & -4.615 & 0.000 & 2 & 0.399 \\
\hline
\end{tabular}

a. Null hypotheses: series has a unit root,

b. Null hypotheses: series is stationary. The $5 \%$ critical value $=0.463$. 


\section{Table 2}

Johansen Cointegration Test Results

Sample (adjusted): 2008M10 2013M12

Included observations: 63 after adjustments

Trend assumption: Linear deterministic trend

Series: $D_{t}, P_{t}$, and $I_{t}$

Lags interval (in first differences): 1 to 2

\begin{tabular}{|c|c|c|c|c|}
\hline \multicolumn{5}{|c|}{ Unrestricted Cointegration Rank Test (Trace) } \\
\hline Hypothesized & & Trace & 0.05 & \\
\hline No. of CE(s) & Eigenvalue & Statistic & Critical Value & P-value ${ }^{a}$ \\
\hline \multicolumn{5}{|c|}{ 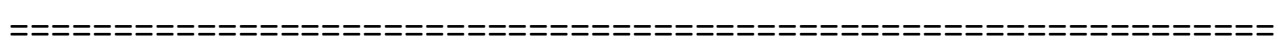 } \\
\hline None ** & 0.296 & 34.600 & 29.797 & 0.013 \\
\hline At most 1 & 0.171 & 12.468 & 15.495 & 0.136 \\
\hline At most 2 & 0.010 & 0.6403 & 3.8415 & 0.424 \\
\hline
\end{tabular}

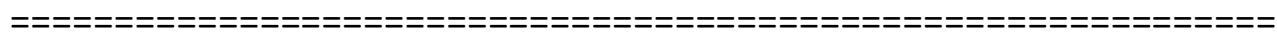

Trace test indicates 1 cointegrating eqn(s) at the 0.05 level

Unrestricted Cointegration Rank Test (Maximum Eigenvalue)

\begin{tabular}{|c|c|c|c|c|}
\hline \\
\hline No. of $\mathrm{CE}(\mathrm{s})$ & Eigenvalue & Statistic & Critical Value & P-value** \\
\hline \multicolumn{5}{|c|}{ 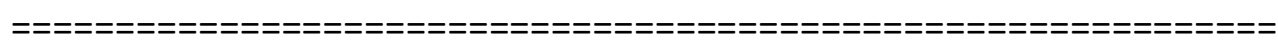 } \\
\hline None ** & 0.2962 & 22.132 & 21.132 & 0.036 \\
\hline At most 1 & 0.1711 & 11.828 & 14.265 & 0.117 \\
\hline At most 2 & 0.0101 & 0.6402 & 3.8415 & 0.424 \\
\hline
\end{tabular}

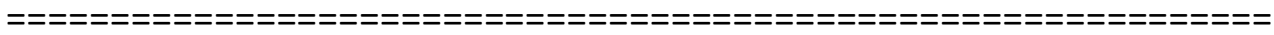

Max-eigenvalue test indicates 1 cointegrating eqn(s) at the 0.05 level

** denotes rejection of the hypothesis at the 0.05 level

a. MacKinnon-Haug-Michelis (1999) p-values 
Dependent Variable: $D_{t}$

Table 3

\section{Dynamic OLS Estimation Results}

Sample (adjusted): 2008M09 2013M11

\begin{tabular}{|c|c|c|c|c|}
\hline \multirow{2}{*}{$\begin{array}{l}\text { Variable } \\
=====-=\end{array}$} & Coefficient & Std. Error & t-Statistic & \multirow{2}{*}{$\begin{array}{c}\text { P-value } \\
\text { ======- }\end{array}$} \\
\hline & & & & \\
\hline C & $-239.232 * * *$ & 77.492 & -3.087 & 0.003 \\
\hline$P_{t}$ & $-0.266^{*}$ & 0.146 & -1.826 & 0.073 \\
\hline$I_{t}$ & $0.008 * * *$ & 0.002 & 3.533 & 0.001 \\
\hline$\Delta P_{t-1}$ & -0.068 & 0.202 & -0.335 & 0.739 \\
\hline$\Delta P_{t}$ & -0.236 & 0.202 & -1.170 & 0.247 \\
\hline$\Delta P_{t+1}$ & $-0.553 * * *$ & 0.204 & -2.713 & 0.009 \\
\hline$\Delta t_{t-1}$ & 0.004 & 0.005 & 0.757 & 0.453 \\
\hline$\Delta t_{t}$ & 0.001 & 0.005 & 0.116 & 0.908 \\
\hline$\Delta t_{t+1}$ & $0.014 * *$ & 0.005 & 2.575 & 0.013 \\
\hline
\end{tabular}

Adjusted R-squared

0.427

Null Hypothesis: DOLS1 long run residuals have a unit root

\begin{tabular}{|c|c|c|}
\hline \multicolumn{3}{|c|}{ t-Statistic } \\
\hline \multicolumn{3}{|c|}{ 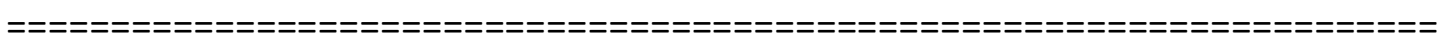 } \\
\hline Residual based cointegration & test statistic & -5.37 \\
\hline \multirow[t]{3}{*}{ E-G Test critical values: } & $1 \%$ level & -4.84 \\
\hline & $5 \%$ level & -4.11 \\
\hline & $10 \%$ level & -3.73 \\
\hline
\end{tabular}

$* * *$ Significant at $1 \%$ level; $* *$ Significant at $5 \%$ level; $*$ Significant at $10 \%$ level 
Table 4

Error Correction Models

Dependent Variable: $\triangle D_{t}$

Sample: 2009M01 2013M12

\begin{tabular}{|c|c|c|c|c|c|c|}
\hline \multirow[b]{2}{*}{ Variable } & \multicolumn{2}{|c|}{ ECM 1} & \multicolumn{2}{|c|}{ ECM 2} & \multicolumn{2}{|c|}{ ECM 2} \\
\hline & Coefficient & $\begin{array}{l}\text { Std. } \\
\text { Error }\end{array}$ & Coefficient & $\begin{array}{l}\text { Std. } \\
\text { Error }\end{array}$ & Coefficient & $\begin{array}{l}\text { Std. } \\
\text { Error }\end{array}$ \\
\hline Constant & $-216.099^{* * *}$ & 28.836 & $-215.548^{* * *}$ & 28.788 & $-212.130^{* * *}$ & 28.856 \\
\hline$\widehat{L R} R_{t-1}$ & $-0.901^{* * *}$ & 0.120 & $-0.899^{* * *}$ & 0.120 & $-0.884^{* * *}$ & 0.121 \\
\hline$\triangle P X C T_{t}$ & -0.077 & 0.183 & -0.076 & 0.183 & -0.037 & 0.185 \\
\hline$\Delta I_{t}$ & $0.011^{* * *}$ & 0.004 & $0.011^{* * *}$ & 0.004 & $0.011^{* * *}$ & 0.004 \\
\hline$\Delta I_{t-5}$ & $0.006^{*}$ & 0.003 & $0.006^{*}$ & 0.003 & $0.007^{*}$ & 0.003 \\
\hline$\triangle C T_{t-3}$ & $-4.050^{* *}$ & 2.017 & & & & \\
\hline$\Delta C T_{t-3} \cdot J_{t-3}$ & & & $-4.175^{* *}$ & 2.038 & & \\
\hline$\Delta C T_{t-3} \cdot J_{t-3}^{09}$ & & & & & -1.974 & 3.598 \\
\hline$\Delta C T_{t-3} \cdot J_{t-3}^{10}$ & & & & & -0.804 & 4.151 \\
\hline$\Delta C T_{t-3} \cdot J_{t-3}^{11}$ & & & & & $-8.193^{* *}$ & 4.017 \\
\hline$\Delta C T_{t-3} \cdot J_{t-3}^{12}$ & & & & & -5.489 & 4.061 \\
\hline$\Delta C T_{t-3} \cdot J_{t+2}^{12}$ & & & & & $7.847^{*}$ & 4.083 \\
\hline Adjusted R-squared & 0.49 & & 0.49 & & 0.58 & \\
\hline $\mathrm{ARCH}(1) \mathrm{LM}$ test (P-value) & 0.39 & & 0.39 & & 0.88 & \\
\hline Corr(1) LM test (P-value) & 0.58 & & 0.54 & & 0.14 & \\
\hline Corr(4) LM test (P-value) & 0.45 & & 0.44 & & 0.21 & \\
\hline Jarque-Bera test (P-value) & 0.32 & & 0.33 & & 0.46 & \\
\hline
\end{tabular}

*** Significant at $1 \%$ level; $* *$ Significant at $5 \%$ level; $*$ Significant at $10 \%$ level 
Figure 1

Public Interest in the B.C. Carbon Tax over Time

(Percentage searches in Google relative to July 2008)

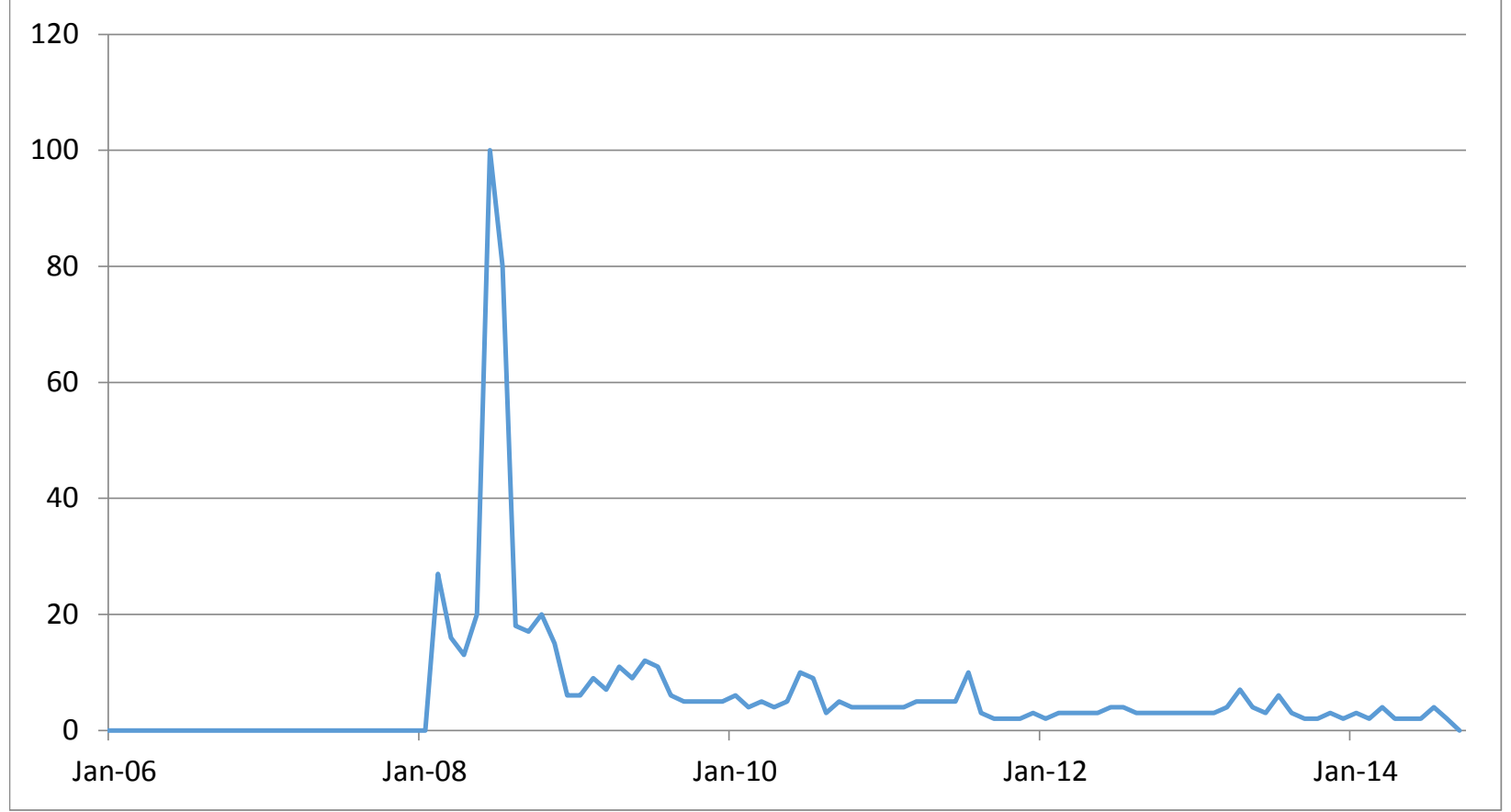

Figure 2

Monthly Diesel Sales (litres per capita)

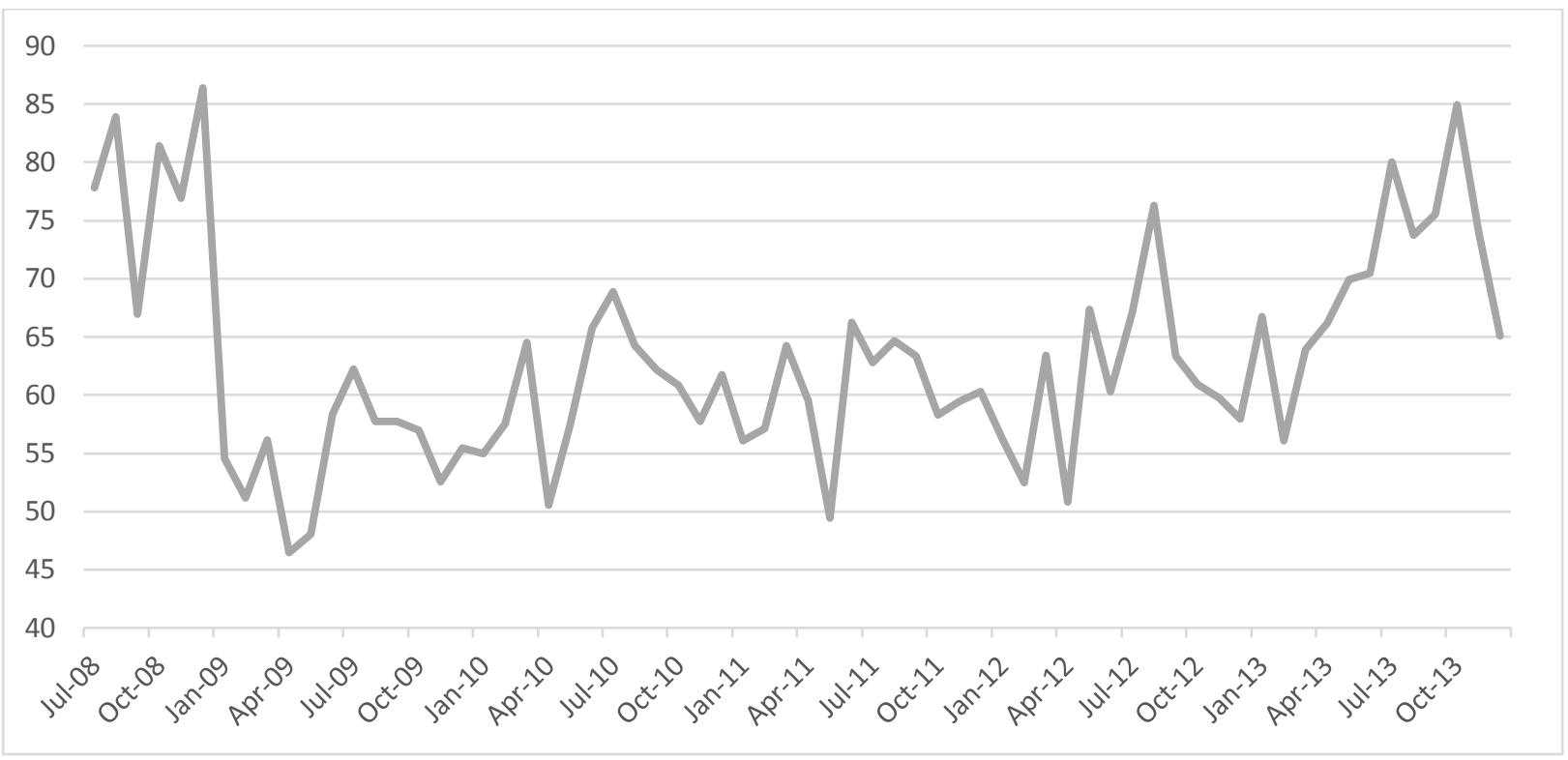


Figure 3

Real Price of Diesel (2007 cents/litre)

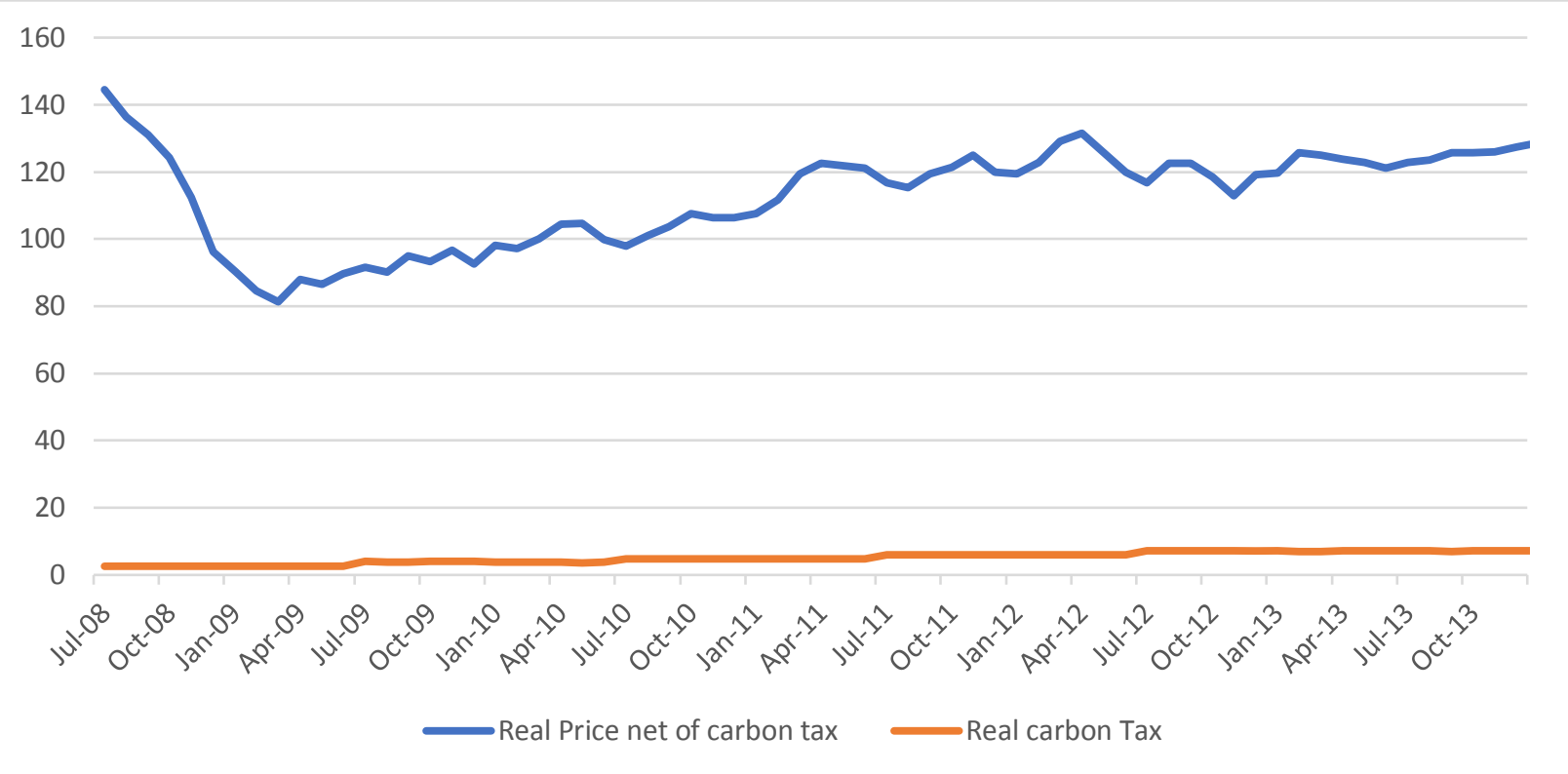

Figure 4

Real GDP per Capita (2007\$)

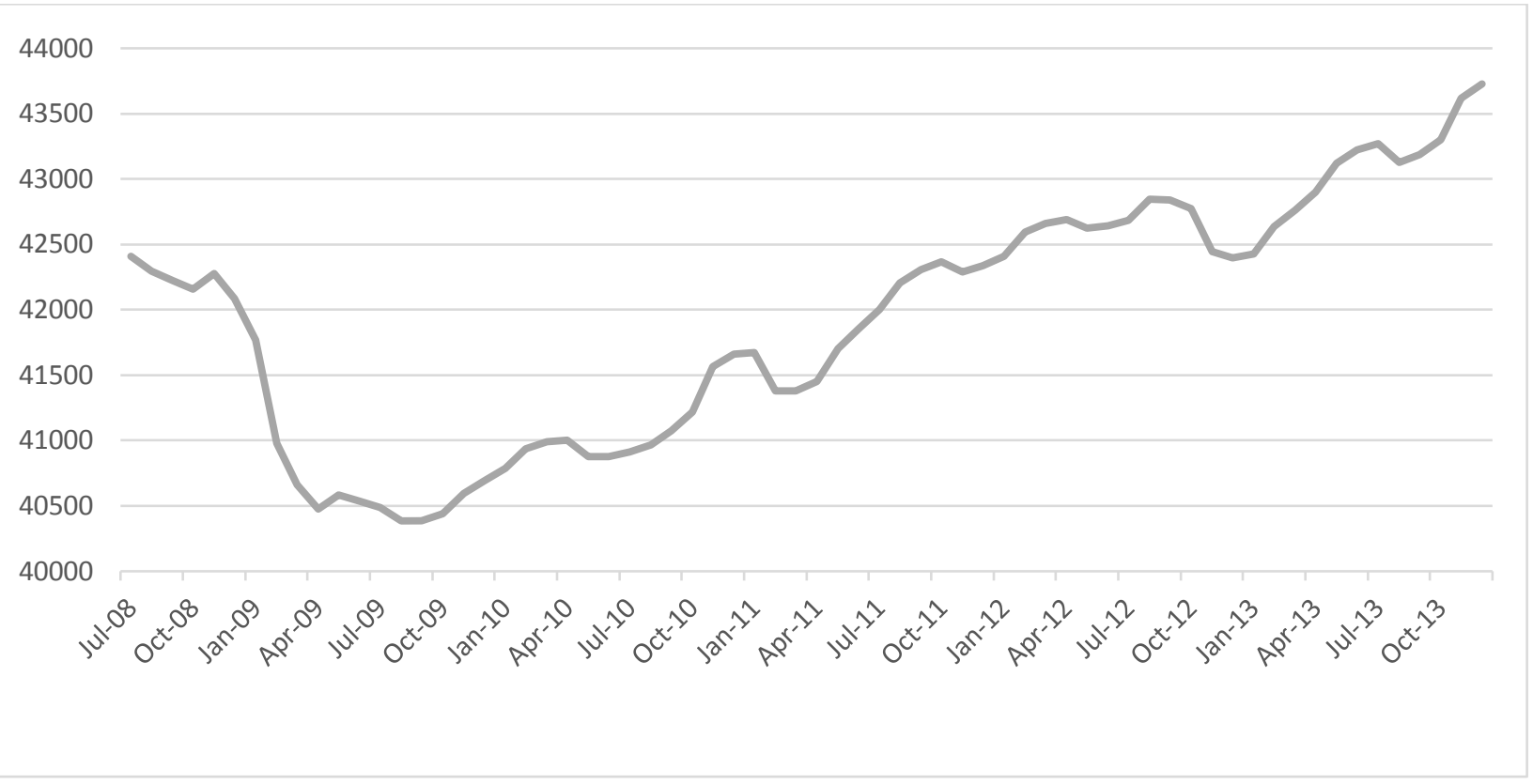




\section{Appendix}

\section{Data Sources}

\begin{tabular}{|c|c|}
\hline Monthly domestic sales of diesel in litre & $\begin{array}{l}\text { Statistics Canada, The Supply and Disposition of Refined } \\
\text { Petroleum Products in Canada, Catalogue no. 45-004-X. } \\
\text { CANSIM, Table 134-0004 }\end{array}$ \\
\hline $\begin{array}{l}\text { Monthly diesel average final price and total taxes } \\
\text { in Vancouver, (c/litre) }\end{array}$ & $\begin{array}{l}\text { Kent Group Ltd., Canada } \\
\text { http://www.kentgroupltd.com/ }\end{array}$ \\
\hline B.C. GDP in $\$ 2007$ dollars & Conference Board of Canada, quarterly \\
\hline Consumer Price index $(2007=100.0)$ & $\begin{array}{l}\text { Statistics Canada, CANSIM Table 326-0020 - Consumer } \\
\text { Price Index (CPI), } 2011 \text { basket, monthly (2002=100). }\end{array}$ \\
\hline B.C. population & $\begin{array}{l}\text { Statistics Canada, CANSIM, Table 051-0005 - Estimates } \\
\text { of population, Canada, provinces and territories, } \\
\text { quarterly (persons). }\end{array}$ \\
\hline
\end{tabular}

